
www.globaljournalseries.com, Email: info@globaljournalseries.com

\title{
EFFECTS OF WEATHERING ON MECHANICAL PROPERTIES OFGRANITE GNEISS AND DOLERITE: A CASE STUDY OF OBAN AND OBUDU BASEMENT ROCKS SOUTH-EASTERN NIGERIA
}

\author{
E. A. AMAH, M. I. ODEN AND G. S. ANAM \\ (Received21September 2011; Revision Accepted 14September 2012)
}

\begin{abstract}
Thispaper describes thegeotechnical characteristics of granite gneiss and dolerite from Oban and Obuduregions in South-eastern Nigeria.The suitability of these rocks for civil construction purposes and the effects of weathering on their mechanical properties are examined. The results indicate that compressive strength ranges from 19.31 to $77.37 \mathrm{MN} / \mathrm{m}^{2}$ and 40.5 to $140.0 \mathrm{MN} / \mathrm{m}^{2}$ for the granite gneiss and dolerite respectively. Their respective Young Modulus ranged 13.60 to $84.20 \mathrm{GPa}$ and 24.45 to $102.50 \mathrm{GPa}$. The low values obtained for compressive strength and Young Modulus in this work are the direct effects of the humid tropical conditions that cause weathering of the rocks at the base of the overburden aided by water. In addition to weathering, structural defects such as fractures, joints, faults and the mechanical drilling process tend to introduce micro-pores/fractures in the samplesthereby leading to a decrease in the strength and modulus of these rocks.Furthermore, the moisture content (W\%) and the degree of weathering decrease with increasing hardness $(H)$, specific gravity $(S G)$,compressive strength $(\alpha)$ and Young Modulus $(E)$. The relationship between moisture content, the degree of weathering and the mechanical properties particularly compressive strength $(\alpha)$ and Young modulus (E)also showsthat the fresh (FR) to slightly weathered(SW) rocks are generally suitable for most civil construction works than the extremely weathered(EW) to highly weathered $(\mathrm{HW})$ rocks.
\end{abstract}

KEYWORDS: BasementRocks,Mechanical Properties,Weathering Grades(FR-EW),Oban/Obudu.

\section{INTRODUCTION}

Basement rocks are known to occur at Oban and Obudu regions ofSouth-eastern Nigeria (Ekwueme 1988, 1990, 2003). These rocks when quarried could provide raw materials for highway pavement aggregates, civil construction works, rip rap for damsand monumental stones at affordable prices. The Oban massif occupies an area of about $10,000 \mathrm{~km}^{2}$ (Ekwueme et. al., 1995) and lies between Longitudes $\left(8^{\circ} 00^{\prime}\right.$ and $\left.8^{0} 55^{\prime} \mathrm{E}\right)$ and latitudes $\left(5^{0} 00\right.$ and $\left.5^{\circ} 45^{\prime}\right)$ while Obudu plateau extends over an area of about $4500 \mathrm{Km}^{2}$ between latitudes $6^{\circ} 00^{\prime} \mathrm{N}$ and $6^{\circ} 45^{\prime} \mathrm{N}$ and longitudes $8^{\circ} 40^{\prime} \mathrm{E}$ and $930^{\prime} \mathrm{E}$ (Fig.1).

E. A. Amah, Department of Geology, University of Calabar, Calabar, Nigeria

M. I. Oden, Department of Geology, University of Calabar, Calabar, Nigeria

G.S. Anam, Department of Geology, University of Calabar, Calabar, Nigeria 




Fig 1.Geological Map of Cross River State

The climate is tropical.There are distinct wet and dry seasons, the former from April to October and the latter from November to March.The areas are underlain by highly deformedPrecambrian crystalline basement rocksmainlygranite, gneisses and schists. These rocks are intruded by pegmatites, granodiorites, charnokites and dolerites(Ekwueme1990,1998).They are deeply weathered in some places tosilty clay(Fig.2) and could affect the assessment of overall modulus and strength of rock performance in engineering works(Amah et. al. 2012).A typical weathering profile in a basement terrain is illustrated in Fig.2. Both granite gneiss and dolerite consist of a wide range of weathering grades: Extremely Weathered(EW), Highly Weathered(HW),Moderately Weathered(MW), Slightly Weathered(SW)andFresh Rock(FR). 


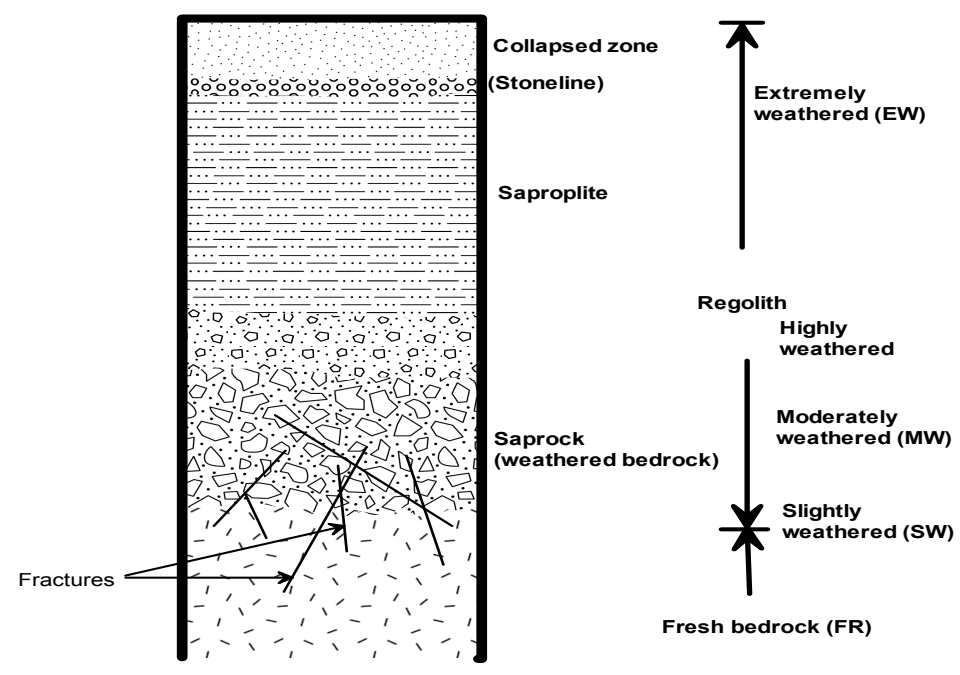

Fig.2: Typical weathering profile in a basement complex terrain(modified from Wright, 1992)

Dolerites are igneous rocks of typically hypabyssal origin having formed as shallow sills and dykes. They may be regarded as equivalents of gabbros of plutonic origin and basalts of volcanic origin. The term diabase is also used for dolerite. They are predominantly made up of calcic plagioclase and are mostly medium to fine grained rocks.Granite gneiss on the other hand, is a megascopically crystalline foliated metamorphic rock characterized by segregation of constituent minerals into layers or bands of micaceous minerals, alternating with bands of equidimensional minerals like feldspars, quartz and garnet etc(Ekwueme 2003).

Granite gneiss and dolerites are quite common in Oban and Obudu basement regions of South-eastern Nigeria. They are extensively used in materials for construction. They are characterized by very high crushing (compressive) strength and hence can be easily trusted in most of construction works. These rocksare typically impervious, hard and strong and form very strong foundations for most civil engineering projects. Granite gneiss and dolerite, fail when subjected to loads beyond their strength. The failure takes place under compressive, tension and shear forces at different values. It is however, the unconfined compressive strength, which is taken as the most important index property of rocks.

The compressive strength of a rock depends on a number of factors such as its mode of formation, its composition, texture and structure, its moisture content and extent (degree) of weathering it has already suffered.

During the last few years, thousands of tests have been carried out on rock strength in different parts of the world. An attempt has been made by Deere and Miller (1966) to classify rocks on the basis of compressive strength range (Table 1).

Table 1:Engineering classification of rocks by Deere and Miller(1966)

\begin{tabular}{|l|l|l|}
\hline Class & Type description & Uniaxial compressive strength $\left(\mathrm{MN} / \mathrm{m}^{2}\right)$ \\
\hline A & Very high strength & $>224.0$ \\
\hline B & High strength & $112.0-224.0$ \\
\hline C & Medium strength & $56.0-112.0$ \\
\hline D & Low strength & $28.0-56.0$ \\
\hline E & Very low strength & $<28.0$ \\
\hline
\end{tabular}


In the area of study, few of the published works have been on the geologyand petrologyofOban/Obudu basement rocks (Rahmanet. al. 1981,Ekwueme1990). Different authors have also established the economic importance ofbasement complex of Nigeria and most importantly, as a good material for civil construction (Rahaman, 1976, Dada 2006, Bale et. al. 2010, Amah et.al.2012). The present paper therefore focuses on the physical and mechanical properties of granite gneiss and dolerite, in particular the effect of weathering on strength and modulus of these rocksfromOban massif and Obudu plateau regions.

\section{METHOD OF STUDY}

\section{Field work}

The bulk of samples for this work were rock cores and powder obtained from drill holes at some of the quarry sites at Oban and Obudu areas. The drill holes locations were accurately surveyed using the Garmin 76 Global Positioning System (GPS) to obtain their latitudes and longitudes as well as the relative elevation data. Each borehole had a maximum depth of $15 \mathrm{~m}$ and samples collected at $3 \mathrm{~m}$ depth intervals were placed in polythene bags which were accurately labeled for laboratory testing. Bulk samples were also obtained from rock outcrops in-situ and cut into cylinder for the compressive strength test/Young modulus.

\section{Laboratory tests}

The following physical and engineering tests were performed on over 60 rock specimens of granite gneiss and 56 samples of doleritefrom some of the quarry sites within the Oban/Obudu regions. These include:

Specific gravity(SG), Hardness(H), moisture content(w), compressive strength( $\alpha$ ) and Young modulus(E). The specific gravity was determined by using a $50 \mathrm{~cm}^{3}$ density bottle. This method was found suitable because the samples were in powder form. The Moh's Hardness $(\mathrm{H})$ is defined as the resistance to scratching by various implements. The scale of Hardness ranges from very soft (grade 1) to very hard (grade 10). Rocks at the sites are composed of mineral aggregates, thus a number of Moh's hardness tests were performed and the average results taken.

Moisture content w\% (the weight of water in the samples to weight of solids) was carried out as described by ASTM $2216-71$.

The uniaxial compressive strength and Young modulus of the rock blocks were also determined using the Universal Testing Machine (UTM) model AXM500-50KN.The compressive strength measurements on standard specimens of $50 \mathrm{~mm}$ in diameter and $50 \mathrm{~mm}$ in length with coplanar end-faces were performed (with an accuracy of $0.1 \%$ ). The load was applied to the end-faces of the specimen with a strain rate of $1,000 \mathrm{~N} / \mathrm{s}$ until failure. The maximum load is defined as the uniaxial compressive strength. The Young's modulus was determined from the stress-strain curve of the uniaxial compressive strength test. The results are presented in Table 2.

\section{RESULTS AND DISCUSSION}

The results of the physical $(H, W \%, S G)$ and mechanical properties $(\alpha, E)$ are shown in Table 2.

Table 2: Summary of physical and mechanical properties of basement rocks(granite gneiss/dolerite) from Southeastern Nigeria

\begin{tabular}{|l|l|l|l|}
\hline $\mathrm{S} / \mathrm{N}$ & Properties & $\begin{array}{l}\text { Granite gneiss } \\
(\mathrm{n}=60)\end{array}$ & Dolerite $(\mathrm{n}=56)$ \\
\hline 1 & Specific gravity $(\mathrm{SG})$ & $1.55-2.73$ & $1.50-2.65$ \\
\hline 2 & Hardness $(\mathrm{H})$ & $1.0-6.0$ & $1.0-6.5$ \\
\hline 3 & Moisture content $(\mathrm{W}) \%$ & $0.11-10.12$ & $0.10-8.40$ \\
\hline 4 & Compressivestrength $(\alpha) \mathrm{MN} / \mathrm{m}^{2}$ & $19.31-77.37$ & $40.5-140.0$ \\
\hline 5 & Young Modulus $(\mathrm{Y}) 10^{3} \mathrm{MN} / \mathrm{m}^{2}$ & $13.60-84.20$ & $24.45-102.50$ \\
\hline
\end{tabular}

$\mathrm{n}=$ number of rock specimens

\section{The specific gravity}

The specific gravity of samples tested ranges from 1.55 (overburden) to 2.73 (fresh granite gneiss)and 1.50 to 2.65 for dolerite. SGtends to increase with increasing rock quality or strength. In a case where the SG shows an unexpected decrease with depth, some weathering of the rocks must have taken place or the fracture might contain water. Fresh rocks at the Oban/Obuduquarry sites generally have SG valuesgreater than 2.40 in both regions while the weathered/overburden depth range usually have SG values less than 2.40 . 


\section{Moisture content (W\%)}

The results (Table 2) reveal that the water content ranges from 0.11 to $10.12 \%$ in both rocks. There is a general decrease in the water content of the samples with increasing depth. That is, more water is contained in the weathered overburden materials than in the sound rock sections. The implication of the decrease of moisture with depth is that fractures (if any) in the rocks at the site also decrease with depth. Hence, swelling pressure potential due to the present of clay mineral resulting from weathering of the aluminosilicates is very low (Edet 1992)

\section{Moh's Hardness (H)}

The hardness $\mathrm{H}$ ranges from 1.0 for weathered soft rock to a value slightly above 6.0 for fresh granite gneiss/dolerite. The low Moh'shardness obtained for overburden materials indicate poor sample quality. Increase hardness is directly related to improve rock quality and strength.

\section{Compressive strength ( $\alpha$ ) and Young modulus( $Y$ )}

The results of the compressive strength of rocks samples at the Oban and Obuduare indicated in Table 2. It ranges from 19.31 to $77.37 \mathrm{MN} / \mathrm{m}^{2}$ and 40.5 to $140.0 \mathrm{MN} / \mathrm{m}^{2}$ for thegranite gneiss and dolerite respectively.Rock strength results reveal slightly low values compared to the standard range values of 80.0 to $250.0 \mathrm{MN} / \mathrm{m}^{2}$ for fresh metamorphic rocks such as gneiss and 100.0 to $350.0 \mathrm{MN} / \mathrm{m}^{2}$ for fresh igneous rockssuch as granite and dolerite (Deere and Miller 1966, Singh2008). Their respective Young Modulus ranged
13.60 to $84.20 \mathrm{GPa}$ and 24.45to $102.50 \mathrm{GPa}$. The low values obtained for compressive strengthand Young Modulus are direct effects of the humid tropical conditions that causes weathering of the rocks at the base of the overburden aided by water. In addition to weathering, structural defects such as fractures,joints,faults and the mechanical drilling process may tend to introduce micro-pores/fractures in the samples(Wang and Simmons 1978, Kowallis1982) thereby leading to a decreasein the strength and modulus of these rocks. These might also be responsible for the slightly lower SG valuesobtained in this work. Generally,themechanical properties of basement rocks in Obudu area tend to be comparatively higher (better rock quality) than those found in Oban region. Rocks in Oban massif are heavily weathered and of higher fracture density than those of Obudu.This observation could be partly due to the fact that Oban is located ina region with high rainfall/thick vegetationwhich accelerate chemical weathering in the rocks of thearea(Amah et.al.2012), and partly due to the tectonic forces operating during the Pan African orogeny thatwas assisted by fluids in reworking of basement fractures in Oban massif than that of Obudu basement (Oden et. al.2012)

\section{Correlation diagrams}

A plot ofunconfined compressive strength $(\alpha)$ versus moisture content(w),(Fig.3)and Young modulus(E) against moisture content (w),(Fig 4) and weathering grades(EWtoFR)for both dolerites and granite gneiss indicate that the higher the moisture content $(w)$, the higher the weathering grades(FR-EW)

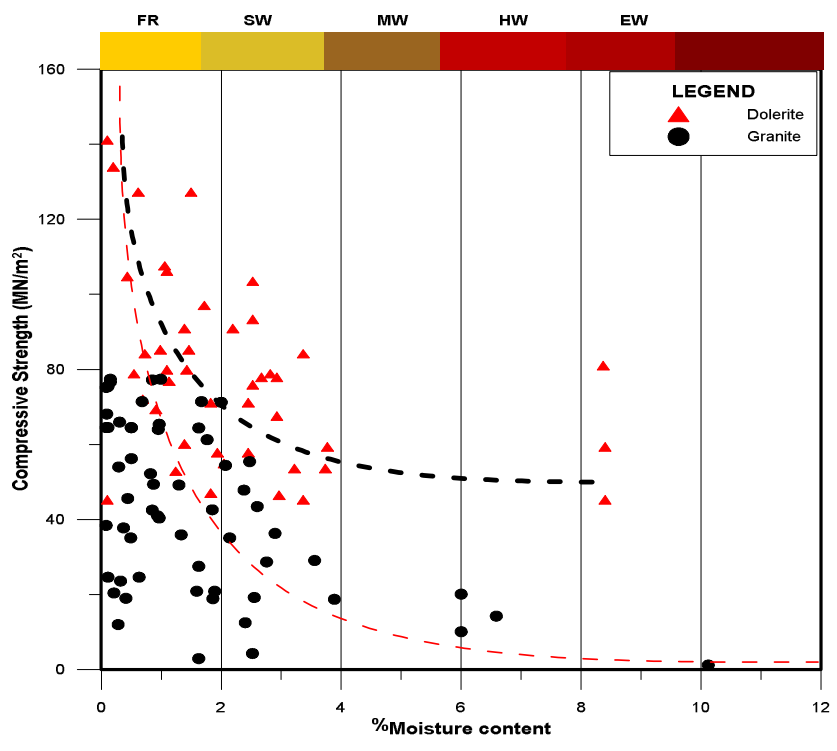

Fig. 3:Compressive Strength vsMoisture Content 


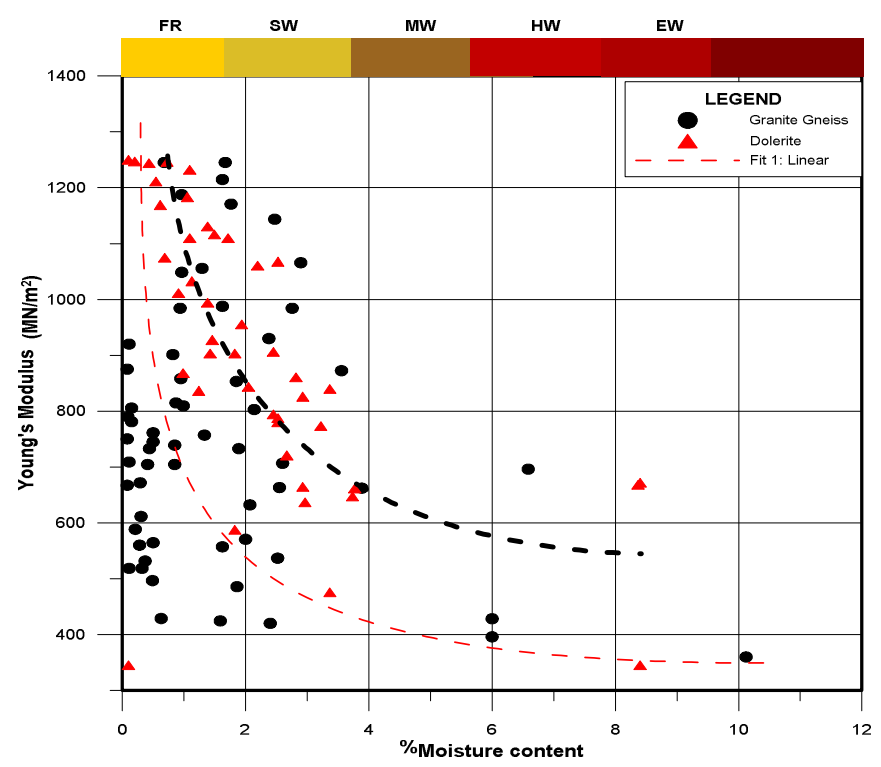

Fig. 4: Young's Modulus vs Moisture content

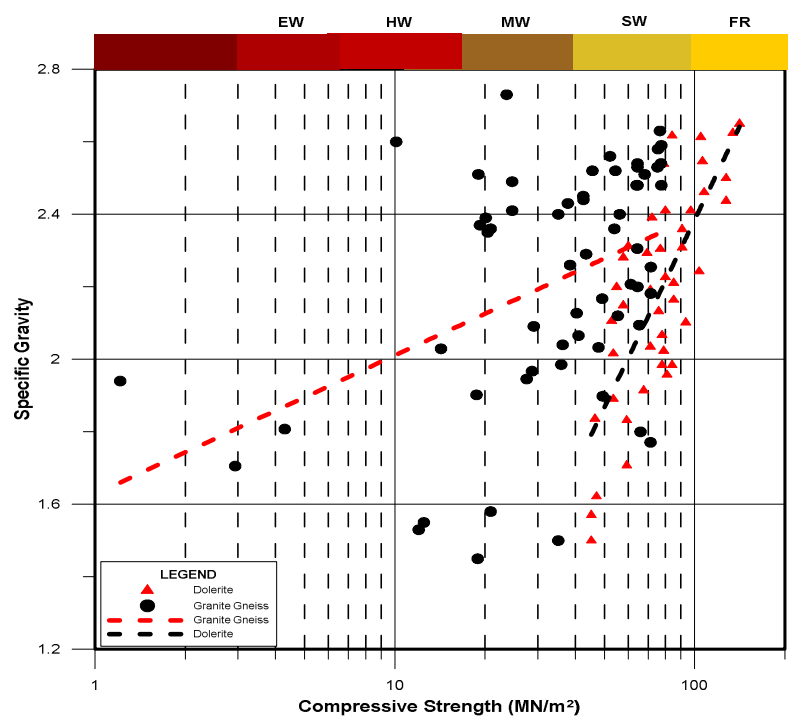

Fig.5: Specific Gravityvs compressive strength 


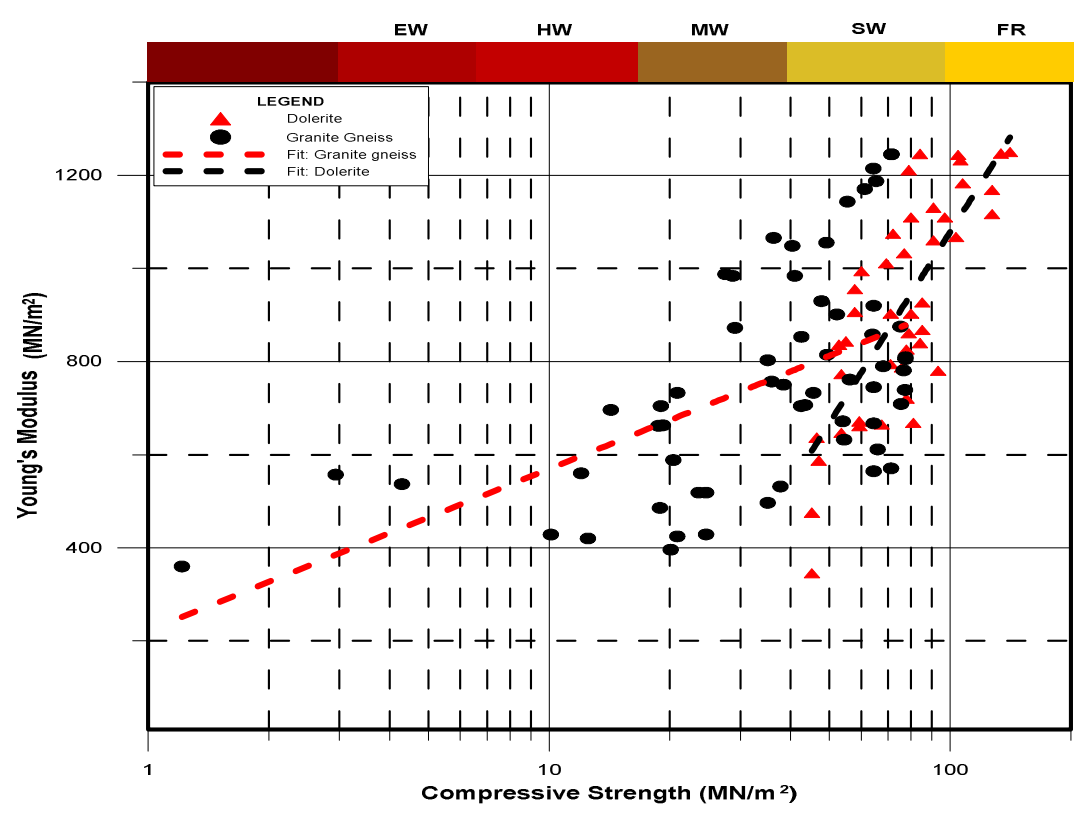

Fig. 6: Young Modulus Vs compressive strength

The diagrams further show a general trend for unconfined compressive strength( $\alpha$ )/YoungModulus(E) decreasing with the increasing moisture content (weathering grades). The data indicates some scatter due to vesicularity of the samples tested as well as inclusion of data biased by joint/fracture influences.

A plot of SG against compressive strength (Fig. 5) and compressive strength versus Young modulus and weathering grades (Fig 6) clearly reveal that the higher the specific gravity SG the higher the compressive strength (or Young Modulus) which implies increasing rock quality with depth and appears to show negative correlation with the degree of weathering.

In-situ identification and field observationshave confirmed that granite gneisses are affected by weathering processes faster than the dolerite because of the presence of foliation planes in gneisses and their complete absence in dolerite. Both rocks, in the presence of water will decay into clay (kaolinite)and silicaaccording to the equation below: $2 \mathrm{KAISi}_{3} \mathrm{O}_{8}+2 \mathrm{H}_{2} \mathrm{O}+\mathrm{CO}_{2} \ldots . . . \mathrm{Al}_{2} \mathrm{Si}_{2} \mathrm{O}_{5}(\mathrm{OH})_{4}+\mathrm{K}_{2} \mathrm{CO}_{3}+4 \mathrm{SiO}_{2}$

(Orthoclase) + Carbonic acid............ (Kaolinite) + Pot.Carbonate+ Silica

Furthermore, in the above equation, sodium $(\mathrm{Na})$ or calcium $(\mathrm{Ca})$ may be present instead of potassium $(\mathrm{K})$ if the mineral in question is another type of feldspar. The main end product, Kaolinite is formed in all such cases. This chemical change in the rock produces definite alteration in the physical constitution of the rock: a soft $(H=1)$ clay mineral is formed in place of a hard mineral (feldspar, $\mathrm{H}=6$ ), thereby affecting the strength of the rock very significantly. Carbonates are removed in solution and silica formed colloids; this chemical weathering processesresultin partial or total conversion of a strong igneous rock like dolerite and metamorphic rocks such as granite gneiss into a mass of soft clay like product in the zone of weatheringbecause feldsparsare their chief constituent minerals(Singh 2008,Amah et. al.2012).

\section{Classification scheme}

The relationship between the degree of weathering(FR-EW), moisture content $(\mathrm{W})$ and mechanical properties particularly compressive strength $(\alpha)$ and Young modulus $(E)$ helps to categorize the rocks into 5 classes A,B,C,D and $E($ Table 3). The fresh rock (FR) and slightly weathered (SW) rock are classified under classes $A$ and $B$ respectively. These rocks have compressive strength $\left(>80 \mathrm{MN} / \mathrm{m}^{2}\right)$ and $\left(80-60 \mathrm{MN} / \mathrm{m}^{2}\right)$ with very low water content $(0-$ $4 \%$ ). Moderately weathered (MW) rocks have a medium compressive strength $\left(60-40 \mathrm{MN} / \mathrm{m}^{2}\right)$, moderate water content (4-6\%)and is classified as class C. Rocks that are highly weathered (HW) and extremely weathered (EW) are put under classes $D$ and $E$ respectively. Class $D$ has low compressive strength $\left(40-20 \mathrm{MN} / \mathrm{m}^{2}\right)$ and high water content (6.0-8\%).However, Class $\mathrm{E}$ are rocks with low compressive strength $<20 \mathrm{MN} / \mathrm{m}^{2}$ andvery high moisture content $>8 \%($ Table 3$)$. 
Table 3: Rock strength in relation to the end use

\begin{tabular}{|c|c|c|c|c|c|}
\hline $\begin{array}{l}\text { Compressive } \\
\text { strength }\left(\mathrm{MN} / \mathrm{m}^{2}\right)\end{array}$ & $\begin{array}{ll}\text { Young modulus } \\
(\mathrm{GPa})\end{array}$ & $\begin{array}{l}\text { Moisture } \\
\text { contents }(\%)\end{array}$ & $\begin{array}{ll}\text { Degree of } \\
\text { weathering }\end{array}$ & Classes & End use \\
\hline $\begin{array}{c}<20.0 \\
\text { (very low) }\end{array}$ & $<10.00$ (very low) & $\begin{array}{c}>8 \\
\text { (very high) }\end{array}$ & EW & $\mathrm{E}$ & $\begin{array}{l}\text { Unsuitable for } \\
\text { embankments } \\
\text { foundation, airfield } \\
\text { and highway } \\
\text { pavement. }\end{array}$ \\
\hline $\begin{array}{c}20.0-40.0 \\
\text { (low) }\end{array}$ & $10.00-20.00$ (low) & $\begin{array}{l}6-8 \\
\text { (high) }\end{array}$ & HW & $\mathrm{D}$ & $\begin{array}{lr}\text { Suitable } & \text { for } \\
\text { foundations } & \text { and } \\
\text { embankments. } & \end{array}$ \\
\hline 40.0-60.0 (medium) & 20.0-30.0(medium) & $\begin{array}{c}4-6 \\
\text { (medium) }\end{array}$ & MW & $\mathrm{C}$ & $\begin{array}{l}\text { Suitable for civil } \\
\text { constructions } \\
\text { works/airfield } \\
\text { pavements }\end{array}$ \\
\hline $\begin{array}{c}60.0-80.0 \\
\text { (high) }\end{array}$ & $30.0-40.0$ (high) & $\begin{array}{l}2-4 \\
\text { (low) }\end{array}$ & SW & $\mathrm{B}$ & $\begin{array}{l}\text { Very suitable for } \\
\text { civil construction } \\
\text { works. }\end{array}$ \\
\hline $\begin{array}{c}>80.0 \\
\text { (very high) }\end{array}$ & $>40.0$ (very high) & $\begin{array}{c}<2 \\
\text { (very low) }\end{array}$ & FR & A & $\begin{array}{l}\text { Most suitable for all } \\
\text { civil construction } \\
\text { works. }\end{array}$ \\
\hline
\end{tabular}

EW - Extremely weathered

HW - Highly Weathered

MW - Moderately Weathered

SW - Slightly Weathered

FR - Fresh Rock

The (FR, SW and MW) rocks are capable of withstanding heavy traffic foundation loads and generally suitable for most civil construction works (Table 3) because of their high strength and almost zero water content(Amah et. al. 2012). 60\% of the test results are within these grades(Fig.5and6). Rock samples whose crushing strength fall in the range (4020) $\mathrm{MN} / \mathrm{m}^{2}$ (class D) are suitable for use in foundations and embankment constructions in-spite of their low compressive strength. About $30 \%$ of the test results presented fall within this category ( Fig.5 and 6). Rock samples with compressive strengths less than $20 \mathrm{MN} / \mathrm{m}^{2}$ (class E) are considered unsuitable for embankments,foundations, air field and highway pavements. This is due to their high water contents and very low compressive strength. The HW-EW rocks (i.e. classes $D$ and $E$ ) are mainly weathered overburden materials which must be removed before engineering loads are placed on them to avoid engineering geological hazards. These overburden materials may not be a waste in all cases. They could be used for filling and reclamation of excavated areas.

\section{CONCLUSION}

The basement rocks of Oban and Obudu in South Eastern Nigeria have experienced various degrees of weathering:Extremely Weathered (EW), Highly Weathered (HW), Moderately Weathered (MW), Slightly Weathered (SW), and Fresh Rocks (FR). Based on the degree of weathering, moisture contents, and the mechanical properties particularly (compressive strength and young modulus $\mathrm{E}$ ) the rocks have been grouped into classes $A, B, C, D$ and $E$. The results indicate that the higher the moisture content the higher the degree of weathering and the lower the compressive strength(or Young modulus) of the rocks.

Generally, on the basis of the assessment scheme (Table 3 ) the fresh rocks(FR) to Slightly weathered(SW) rocks from Oban/Obudubasement grouped into classesA and Bshow a better rock quality than the highly and extremely weathered overburden (HW-EW) rocks(classes $D$ and E). They are judged adequate for road constructions, airfield pavement, foundationsand other civil engineering works, irrespective of the humid tropicalweather conditions. Class $\mathrm{C}$ is regardedas intermediate or transitional. The overburden materials(HW-EW) must be removed before loads are placed on the foundation ortransported to elsewhere to be used for filling and reclamation of excavated areas.

\section{REFERENCES}

AmahE. A.,Esu, E. O. Oden, M.I. and Anam, G.S.,2012.Evaluation of Old Netim Basement Rocks (South- Eastern Nigeria) for Construction Aggregates. Journal of Geographyand Geology 4(3):90-98

ASTM-2938 - 79, 1980. Standard method of test for compressive strength of rock core specimens. In 1980 Annual Book of ASTM standards part 19; $440-443$.

EFFECTS OF WEATHERING ON MECHANICAL PROPERTIES OF G 
Bale R. B.,Bayewu, O.O.,Folononsol. O., and Oloruntola, M. O., 2010. Estimation of reserveoverburden ratio of a proposed quarry site using resistivity survey: A case study of Ajebo near Abeokuta, South Western Nigeria. World Applied Sciences Journal 10 (8): 963-971.

Dada S. S., 2006. Proterozoic evolution of Nigeria. In: O. Oshin (Ed.). The basement complex of Nigeria and its mineral resources. M.A.Rahaman symposium : $29-44$.

Deere D. U.and Miller, R. P.,1966. Engineering classification and index properties of intact rock.ReportAWFLTR-65-116.Airforce Weapons Laboratory (WLDC) Kirt-land Airforce Base, New Mexico.

Edet A. E., 1992. Physical properties and indirect estimation of micro fracture using Nigeria carbonate rock as example. Eng. Geol(33):7180

Ekwueme B. N., 1988. The Kibaran rocks of Nigeria, West Africa.IGCP No.255 Newsl.,1:15-18.

EkwuemeB. N., 1990. Rb - Sr ages and petrologic features of Precambrian rocks of Oban Massif southeastern Nigeria. Precambran research 47; $267-286$.

Ekwueme B. N., Nyong, E. E. and Petters, S. W., 1995. Geological excursion guide book to Oban Massif, Calabar Flank and Mamfeembayment, S. E. Nigeria. Dc Ford Publisher's Ltd.

Ekwueme B. N., 2003.The Precambrian Geology and Evolution of the Southeastern Nigeria Basement complex. University of Calabar Press, 135p.

Esu E .O., Edet, A.E.TemeS. C.,Okereke C.S., 1994. Study of some Nigeria carbonate rocks for the building construction industry. Eng.Geol .37:271-283.
Kowallis B.,1982.Velocity behavior of rocks related to micro cracks, micro pores and pore fillings. $\mathrm{Ph}$. D. thesis Univ. Wisconsin, Madisin,Wisconin.

Oden M. I.,Okpamu T.A. and AmahE. A., 2012. Comparative Analysis of Fracture Lineaments in Oban and Obudu areas S.E. Nigeria. Journal of Geography and Geology 4(2):36-47.

Rahaman M. A,. 1976. Review of the basement geology of southwestern Nigeria. In Kogbe, C. A. (ed.). Geology of Nigreia. Elizabethan pub. Co. Lagos pp $45-58$.

Rahman A. M.S., Ukpong E. E. and Azumatullah, M.. 1981. Geology of parts of Oban massif Southeastern Nigeria. Journal of mining and geology 18 (1): pp $60-65$.

SinghP.,2008.Engineering and General Geology. Kataria and sons pub. New Delhi.

Sprunt E. S. and Brace, W. F., 1974. Direct observation of microcarvitiesin crystalline rocks. J. Rocks Min. Sci. GeomechAbst. 11: 139 - 150.

Teme S. C. and Edet, A. E., 1986. Strength characteristics of some Nigerian limestone implications for the construction industry. In I. O. Nyambok and K. F. Jeddoh (Editors). Proc. Regional seminar in Earth Sciences, $1^{\text {st }}$ ANST 1 - UNESCO Earth Sciences. Subnetwork, Daker, Senegal pp 8-17.

Ukwang E. E.,Ekwueme, B. N., and Horsley, R. J. 2003. Petrology of granulite faciesrocks in Ukwortung area of Obudu plateau, Southeastern Nigeria. Global J. Geol. Sci. 1(2) :159-167.

WangH. F. and Simmons G., 1978. Microcracks in crystalline rock from5.3kmdepth in the Michigan Basin. J. Geophys. Res., 83 (B12):5849- 5856 .

Wright E. P., 1992. The hydrogeology of crystalline basement aquifers in Africa. In Wright EP, Burgress W G(edn). Geological Society Special Publication 66:1-27. 